\title{
Broiler litter applications and chemical properties of highly weathered soils ${ }^{1}$
}

\author{
Miguel A. Muñoz ${ }^{2}$ and Ulises Chardón-Alcázar ${ }^{3}$
}

J. Agric. Univ. P.R. 96(3-4):129-138 (2012)

\begin{abstract}
The effect of broiler litter application s on chemical properties of three highly weathered soils of different mineralogy was evaluated. The soils included in the study were Coto (very fine, kaolinitic, isohyperthermic Typic Eutrustox), Consumo (fine, mixed, semiactive, isohyperthermic Typic Haplohumults), and Corozal (very fine, parasesquic, isohyperthermic Typic Hapludults). Five broiler litter treatments $(0,5,10,15$ y $20 \mathrm{t} / \mathrm{ha})$ were evaluated in a Complete Randomized Block Design with four replications. The soils were incubated for two months at room temperature $\left(23^{\circ} \mathrm{C}\right)$. Broiler litter did not increase significantly the $\mathrm{pH}$ of the soils; however, soil exchangeable $\mathrm{Al}^{3+}$ decreased in all soils as a result of broiler litter applications. Exchangeable $\mathrm{Al}^{3+}$ in Coto soil decreased from $0.21 \mathrm{cmol} / \mathrm{kg}$ in the 0 broiler litter treatment to 0.09 $\mathrm{cmolc} / \mathrm{kg}$ in the 20 t/ha treatment, in Consumo soil from 1.08 to $0.19 \mathrm{cmol} / \mathrm{kg}$, and in Corozal soil from 7.57 a $5.76 \mathrm{cmol} / \mathrm{kg}$. The treatments also increased electrical conductivity of the soils, such an effect being more evident in Coto soil. The 20 tha treatment increased soil electrical conductivity of Coto by $74 \%$, whereas for Consumo and Corozal soils the increase was only 55 and $54 \%$, respectively. Available P content in Coto soil increased from $40 \mathrm{mg} / \mathrm{kg}$ in the check treatment, to $65 \mathrm{mg} / \mathrm{kg}$ in the 20 tha manure treatment. In Consumo and Corozal soils no significant change in available $\mathbf{P}$ was observed. This finding is indicative of the high P fixing capacity of these soils. It is suggested that soil exchangeable $\mathrm{A}^{3+}$ in Consumo and Corozal soils is reacting with $P$ in the manure, forming aluminum phosphates and contributing to phosphate fixation. Broiler litter application increased exchangeable $\mathrm{K}^{+}$and $\mathrm{Mg}^{2+}$, but not exchangeable $\mathrm{Ca}^{2+}$, in the three soils; exchangeable $\mathrm{Mn}^{2+}$ increased in Consumo and Coto soils.
\end{abstract}

Key words: exchangeable $\mathrm{Al}^{3+}$, broiler litter, chicken manure, $\mathrm{P}$ fixation

\section{RESUMEN}

Aplicaciones de gallinaza afectan las propiedades químicas de suelos altamente meteorizados

Se evaluó el efecto de aplicaciones de gallinaza en las propiedades químicas de tres suelos altamente meteorizados, pero de diferente mineralogía. Los suelos utilizados fueron Coto (bien fino, caolinítico,

${ }^{1}$ Manuscript re-submitted to Editorial Board 30 April 2012.

${ }^{2}$ Professor of Soil Science, Department of Crops and Agroenvironmental Sciences, University of Puerto Rico, Mayagüez.

${ }^{3}$ Soil Chemist (Retired), Tropical Agriculture Research Station, USDA, Mayagüez, Puerto Rico. 
isohipertérmico Eutrustox Típico), Consumo (fino, mixto, semiactivo, isohipertérmico Haplohumults Típico), y Corozal (bien fino, parasesquic, isohipertérmico Hapludults Típico). Se evaluaron cinco tratamientos de gallinaza $(0,5,10,15$ y $20 \mathrm{t} / \mathrm{ha})$ en un diseño de bloques al azar, con cuatro repeticiones. Los suelos con sus respectivos tratamientos se incubaron a una temperatura promedio de $23^{\circ} \mathrm{C}$ por dos meses. Las aplicaciones de gallinaza no afectaron significativamente el $\mathrm{pH}$ de los suelos. Sin embargo, el contenido de $\mathrm{Al}^{3+}$ intercambiable disminuyó en los tres suelos con las aplicaciones de gallinaza. En el suelo Coto el $\mathrm{Al}^{3+}$ intercambiable disminuyó de $0.21 \mathrm{cmol} / \mathrm{kg}$ en el tratamiento sin gallinaza, a $0.09 \mathrm{cmol}_{\mathrm{c}} /$ $\mathrm{kg}$ con la aplicación de 20 t/ha. En el suelo Consumo la disminución de $\mathrm{Al}^{3+}$ intercambiable fue de 1.08 a $0.19 \mathrm{cmol} / \mathrm{kg}$, y en el suelo Corozal fue de 7.57 a $5.76 \mathrm{cmol} / \mathrm{kg}$, para los mismos tratamientos. Los tratamientos de gallinaza aumentaron significativamente la conductividad eléctrica del suelo, siendo este efecto más marcado en el suelo Coto. La aplicación de 20 tha de gallinaza aumentó la conductividad eléctrica del suelo Coto en un $74 \%$, mientras que para los suelos Consumo y Corozal este parámetro aumentó en 55 y $54 \%$, respectivamente. El contenido de $\mathrm{P}$ disponible del suelo Coto aumentó de $40 \mathrm{mg} / \mathrm{kg}$ en el tratamiento sin gallinaza a $65 \mathrm{mg} / \mathrm{kg}$ con la aplicación de 20 t/ha de gallinaza. En los suelos Consumo y Corozal no se observó cambio significativo en este parámetro, lo que indica una alta capacidad de estos suelos para fijar P. La alta capacidad para fijar P está relacionada al alto contenido de $\mathrm{Al}^{3+}$ intercambiable de los suelos Consumo y Corozal y la formacioń de fosfatos de aluminio. El contenido de $\mathrm{K}^{+}$y $\mathrm{Mg}^{2+}$ intercambiable de los tres suelos aumentó con las aplicaciones de gallinaza, no así el contenido de $\mathrm{Ca}^{2+}$ intercambiable; el $\mathrm{Mn}^{2+}$ intercambiable aumentó en los suelos Consumo y Coto.

Palabras clave: $\mathrm{Al}^{3+}$ intercambiable, gallinaza, fijacioń de $\mathrm{P}$

\section{INTRODUCTION}

The use of broiler litter as fertilizer for crops provides a useful and practical way for its disposal. The material is an excellent source of nitrogen, potassium and phosphorus. Also, it can provide significant amounts of calcium and magnesium. In addition to its nutrient content, the beneficial impact of broiler litter stems from its effect on soil properties. Animal manures may provide to the soil organic matter, which can decrease aluminum toxicity. Several researchers have reported that addition of animal manure to highly weathered acid soils increase soil pH (Hue, 1992; O'Hallorans et al., 1997; Wong et al., 1998; Whalen et al., 2000; Mokolobate and Haynes, 2002, 2003). O'Hallorans et al. (1997) also reported an increase in exchangeable basic cations and available $\mathrm{P}$ in an Oxisol, as a result of broiler litter applications and a decrease in exchangeable $\mathrm{Al}^{3+}$. In alkaline soils, broiler litter applications have been reported to decrease the $\mathrm{pH}$ (O'Hallorans et al., 1993).

The mechanisms involved in the reduction of exchangeable $\mathrm{Al}^{3+}$ and other $\mathrm{Al}$ forms are not well established. Haynes and Molokobate (2001) 
suggested as possible mechanisms for soil amelioration an increase in soil $\mathrm{pH}$ as the result of organic matter decomposition, complexation of $\mathrm{Al}$ in solution by soluble organic matter and complexation of exchangeable $\mathrm{Al}$ by the solid phase of organic matter. Tang et al. (2007) suggested that the inorganic and organic $P$ present in significant quantities in manure may complex $\mathrm{Al}$ and decrease its activity in soil solution. These authors observed a significant correlation with organic carbon and phosphorus content of the manure, and the decrease in exchangeable Al.

Inadequate use of broiler litter can have a negative impact on soils and the surrounding environment. Intensive applications of broiler litter to soils may result in contamination problems due to excessive $\mathrm{N}$ and $\mathrm{P}$ content. Nitrogen is weakly retained by soils and move freely with water through the soil profile. Phosphorus can be strongly adsorbed, especially by highly weathered soils where kaolinite and iron and aluminum oxides dominate the mineralogy (Fox et al., 1982; Guzman et al., 1994). However, serious contamination of water reservoirs by $\mathrm{P}$ can occur as the result of soil erosion and soluble $\mathrm{P}$ fractions in soils, once the soil capacity to retain $\mathrm{P}$ is saturated by intensive and continuous manure applications (Martínez et al., 1999).

The beneficial effects of manure applications on the fertility of highly weathered soils and the capacity of such soils to assimilate intensive manure applications need further evaluation. A laboratory experiment was conducted to evaluate the effect of broiler litter on selected chemical properties of three highly weathered soils. Special attention was given to the interaction between exchangeable $\mathrm{Al}^{3+}$ content of the soils, $\mathrm{pH}$ and $\mathrm{P}$ availability.

\section{MATERIALS AND METHODS}

The soils included in the study were Consumo (clayey, mixed, isohyperthermic Typic Haplohumult), Corozal (clayey, mixed, isohyperthermic Aquic Haplohumult) and Coto (very-fine, kaolinitic, isohyperthermic Typic Hapludox) (Beinroth et al., 2003). Five broiler litter treatments $(0,5,10,15$ and $20 \mathrm{t} / \mathrm{ha})$ were evaluated, arranged in a Complete Randomized Block Design, with four replications. Soil chemical parameters evaluated were $\mathrm{pH}$, electrical conductivity, available $\mathrm{P}$, and exchangeable $\mathrm{K}^{+}, \mathrm{Ca}^{2+}, \mathrm{Mg}^{2+}$ and $\mathrm{Al}^{3+}$. Triplicate samples of broiler litter were analyzed for total nutrient content and $\mathrm{Al}$ content. The samples were dry ashed at $500^{\circ} \mathrm{C}$ and digested in $20 \mathrm{ml}$ of $33 \% \mathrm{HCl}$. Nitrogen was analyzed by the micro Kjeldhal method. Phosphorus was analyzed colorimetrically with ammonium vanadate + ammonium molybdate in $\mathrm{HNO}_{3}$ solution. The absorbance was measured at $470 \mathrm{~nm}$ 
with a Perkin Elmer Lambda 3b UV-visible spectrophotometer ${ }^{4}$. Total $\mathrm{K}, \mathrm{Ca}, \mathrm{Mg}, \mathrm{Fe}, \mathrm{Mn}, \mathrm{Zn}$ and $\mathrm{Al}$ in the manure were analyzed by atomic absorption spectroscopy, by using a Perkin Elmer Analyst 300.

The soils were allowed to dry at room temperature, ground and sieved to pass a 20 -mesh sieve. Twenty 200 -g portions of each soil were weighed and mixed with the corresponding manure rate and moistened with $50 \mathrm{ml}$ of distilled water. The moist soil was placed in glass jars and covered with parafilm. Small holes were made on the parafilm cover to enhance gas exchange. The samples were incubated for two months at room temperature and weighed weekly to monitor water loss. Distilled water was added to keep the samples at constant weight. At the end of the incubation period, the soils were analyzed for the indicated chemical parameters. The $\mathrm{pH}$ was measured in a $2: 1$, water:soil ratio. Exchangeable $\mathrm{Ca}^{2+}, \mathrm{Mg}^{2+}, \mathrm{K}^{+}$, and $\mathrm{Mn}^{2+}$ were extracted with $1 \mathrm{~N}$ ammonium acetate solution ( $\mathrm{pH} 7$ ), and determined by atomic absorption spectroscopy (AAS), using a Perkin Elmer Analyst 300. Exchangeable Al was extracted with $1 \mathrm{~N} \mathrm{KCl}$ solution and determined by AAS. The electrical conductivity was measured in a 2:1 water:soil ratio, using a EP Meter Mylon L Co. Available P was extracted by the Bray II method and measured colorimetrically at $882 \mathrm{~nm}$, by using a Perkin Elmer Lambda $3 \mathrm{~b}, \mathrm{UV}$-visible spectrophotometer.

The data was statistically analyzed by Analysis of Variance and mean comparisons by the Tukey test.

\section{RESULTS AND DISCUSSION}

The chemical composition of the broiler litter was as follows: N, $3.65 \% ; \mathrm{P}, 1.78 \% ; \mathrm{K}, 3.32 \%$; Ca, $2.91 \% ; \mathrm{Mg}, 0.66 \% ; \mathrm{Fe}, 2,149 \mathrm{mg} / \mathrm{kg}$; $\mathrm{Mn}, 500 \mathrm{mg} / \mathrm{kg} ; \mathrm{Zn}, 428 \mathrm{mg} / \mathrm{kg}$; and $\mathrm{Al}, 1,341 \mathrm{mg} / \mathrm{kg}$. The broiler litter treatments significantly decreased soil exchangeable $\mathrm{Al}^{3+}$ in Consumo and Corozal soils (Figure 1). The application of $20 \mathrm{t} / \mathrm{ha}$ of broiler litter decreased soil exchangeable $\mathrm{Al}^{3+}$ from 1.08 to 0.19 $\mathrm{cmol} / \mathrm{kg}$ in Consumo soil, and from 7.57 to $5.76 \mathrm{cmol}_{\mathrm{c}} / \mathrm{kg}$ in Corozal soil. Exchangeable $\mathrm{Al}^{3+}$ of Coto soil decreased from 0.21 to 0.09 $\mathrm{cmol} / \mathrm{kg}$; however, this decrease was not statistically significant. No significant change in soil $\mathrm{pH}$ was observed with broiler litter applications (Table 1 ).

\footnotetext{
${ }^{4}$ Company or trade names in this publication are used only to provide specific information. Mention of a company or trade name does not constitute a warranty of equipment or materials by the Agricultural Experiment Station of the University of Puerto Rico, nor is this mention a statement of preference over other equipment or materials.
} 


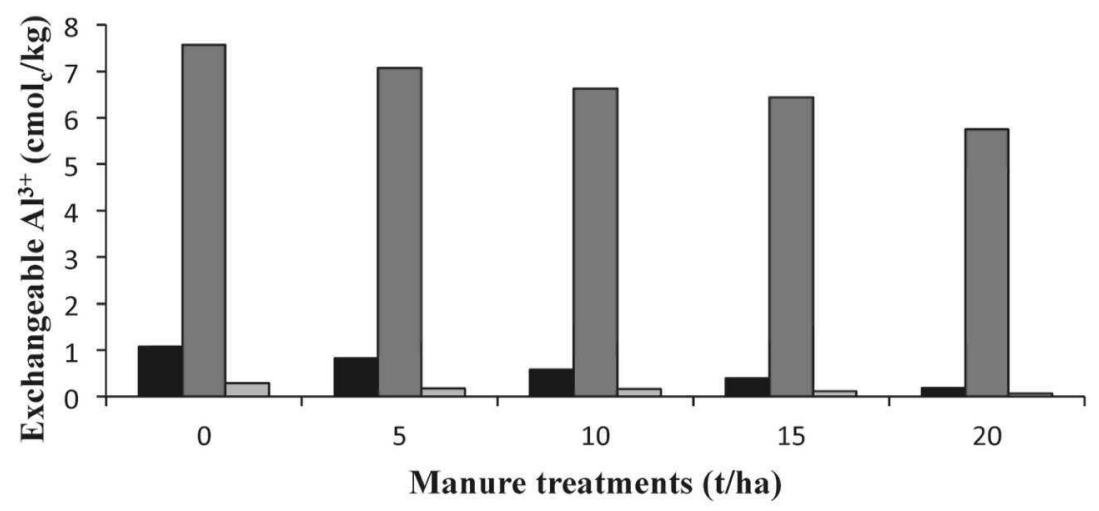

- Consumo $\square$ Corozal $\square$ Coto

FIGURE 1. Soil exchangeable $\mathrm{Al}^{3+}\left(\mathrm{cmol}_{\epsilon} \mathrm{kg}\right)$ as result of broiler litter applications.

Soil electrical conductivity increased significantly in Coto soil, but not in Consumo or Corozal soils (Figure 2). Electrical conductivity in Coto soil increased from $193 \mu \mathrm{mhos} / \mathrm{cm}$ to $766 \mu \mathrm{mhos} / \mathrm{cm}$ with the application of $20 \mathrm{t} / \mathrm{ha}$ of broiler litter. This represents a $74 \%$ increase in electrical conductivity of Coto soil. Coto soil has a lower CEC than Consumo and Corozal, favoring a larger increase in ionic strength of the soil solution and in electrical conductivity.

Soil available P (Bray II) in Consumo and Corozal soils was not affected by broiler litter applications; however, a significant increase in available $\mathrm{P}$ was observed in Coto soil (Figure 3 ). Although Coto soil is an Oxisol, its phosphorus adsorption capacity is significantly lower than the adsorption capacity of Consumo and Corozal soils. In fact, Coto soil ranked eighth in $\mathrm{P}$ adsorption capacity among ten highly weathered soils evaluated by Fox (1982). Since the broiler litter con-

TABLE 1. Soil pH as result of broiler litter applications.

\begin{tabular}{lccccc}
\hline & \multicolumn{5}{c}{ Broiler litter (t/ha) } \\
\cline { 2 - 6 } Soils & 0 & 5 & 10 & 15 & 20 \\
\hline Consumo & $4.75 \mathrm{a}^{1}$ & $4.76 \mathrm{a}$ & $4.91 \mathrm{a}$ & $5.03 \mathrm{a}$ & $5.15 \mathrm{a}$ \\
Corozal & $4.26 \mathrm{a}$ & $4.42 \mathrm{a}$ & $4.34 \mathrm{a}$ & $4.43 \mathrm{a}$ & $4.46 \mathrm{a}$ \\
Coto & $4.68 \mathrm{a}$ & $4.67 \mathrm{a}$ & $4.53 \mathrm{a}$ & $4.75 \mathrm{a}$ & $4.65 \mathrm{a}$ \\
\hline
\end{tabular}

${ }^{1}$ Means followed by the same letter or sequence of letters on each row are not significantly different at the $5 \%$ confidence level by the Tukey test. 


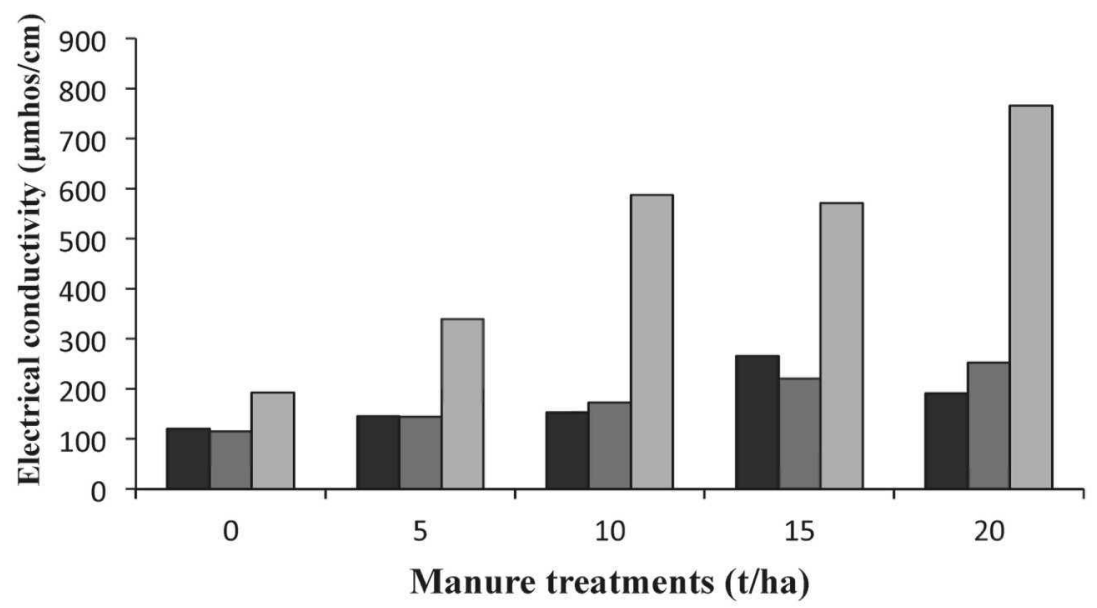

$\square$ Consumo $\square$ Corozal $\square$ Coto

FIGURE 2. Soil electrical conductivity ( $\mu \mathrm{mhos} / \mathrm{cm}$ ) as result of broiler litter applications.

tains $1.78 \% \mathrm{P}$, the total amount of $\mathrm{P}$ added with the application of $5 \mathrm{t} /$ ha was $39.5 \mathrm{mg} / \mathrm{kg}$. The corresponding amount for the $10 \mathrm{t} / \mathrm{ha}$ treatment was $79.0 \mathrm{mg} / \mathrm{kg}$; for the $15 \mathrm{t} / \mathrm{ha}$ it was $118.5 \mathrm{mg} / \mathrm{kg}$; and for the $20 \mathrm{t} / \mathrm{ha}, 158 \mathrm{mg} / \mathrm{kg}$. All the available P provided by the broiler litter was retained in unavailable forms by Consumo and Corozal soils, thus indicating a high $\mathrm{P}$ fixing capacity in these soils. The clay fraction of these soils contains significant quantities of iron and aluminum oxides such as goethite, hematite and gibbsite (Mount and Lynn, 2004). These oxides play an important role in the fixation of phosphorus through specific adsorption reactions (Jones et al., 1982; Fox, 1982). However, size and crystallinity of the oxide fraction are also determinative in $\mathrm{P}$ adsorption capacity. Larger particle size and higher crystallinity decrease $\mathrm{P}$ adsorption capacity of the oxide fraction (Bigham et al., 1978).

In addition to their oxide content, Consumo and Corozal soils have a higher exchangeable $\mathrm{Al}^{3+}$ content than Coto. This finding suggests the possibility that available phosphorus in the broiler litter, in addition to being adsorbed to soil minerals, is reacting with exchangeable $\mathrm{Al}^{3+}$ to form insoluble $\mathrm{Al}$-phosphates. This finding is supported by the fact that although no significant increase in $\mathrm{pH}$ was observed in the soils, exchangeable $\mathrm{Al}^{3+}$ decreased significantly in Consumo and Corozal soils. The largest decrease in exchangeable $\mathrm{Al}^{3+}$ was observed in 


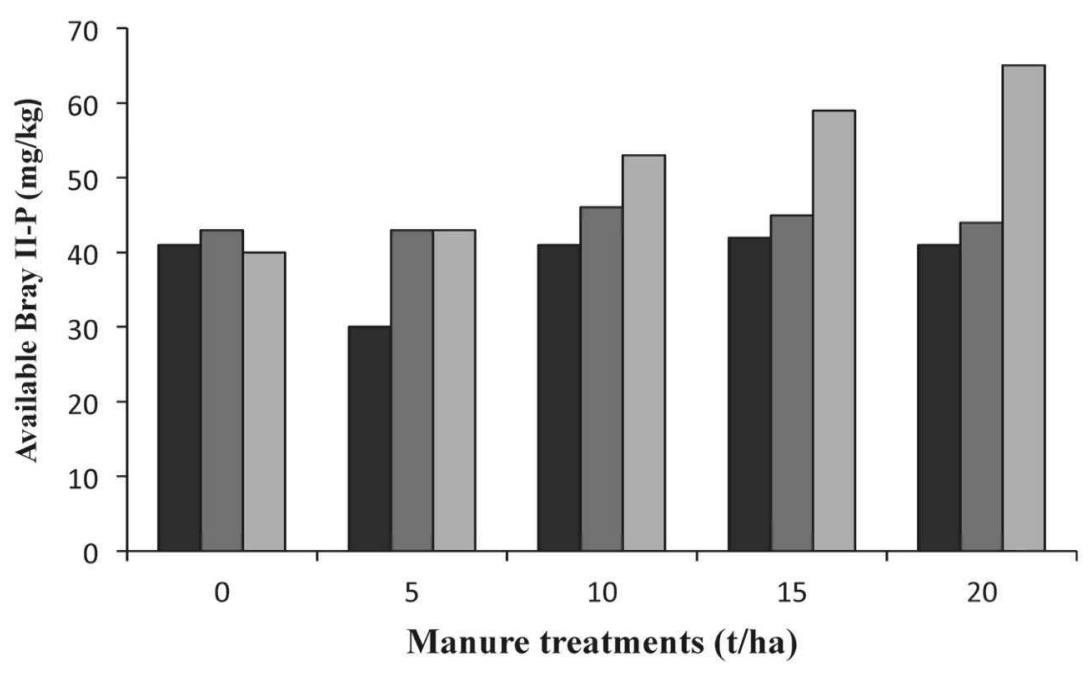

- Consumo $\quad \square$ Corozal $\square$ Coto

FIGURE 3. Soil available $\mathrm{P}(\mathrm{mg} / \mathrm{kg})$ as result of broiler litter applications.

the Corozal soil, which contains the highest level of exchangeable $\mathrm{Al}^{3+}$, followed by Consumo and Coto soils (Figure 1). Exchangeable $\mathrm{Al}^{3+}$ in Corozal soil decreased from 7.57 in the 0 t/ha broiler treatment to 5.76 $\mathrm{cmol}_{\mathrm{c}} / \mathrm{kg}$ in the $20 \mathrm{t} / \mathrm{ha}$ treatment; in Consumo soil from 1.08 to 0.19 $\mathrm{cmol}_{\mathrm{c}} / \mathrm{kg}$; and in Coto soil from $0.29 \mathrm{cmol}_{\mathrm{c}} / \mathrm{kg}$ to $0.09 \mathrm{cmol} / \mathrm{kg}$.

The low levels of exchangeable $\mathrm{Al}^{3+}$ in Coto soil will result in a lower $\mathrm{P}$ fixing capacity than in Consumo and Corozal soils. The results also indicate that the amount of available $\mathrm{P}$ added in the form of manure is enough to saturate the P fixing capacity of Coto soil, thus increasing significantly the level of available P. Similar results were reported by Jang et al. (2007). These authors found that poultry litter and that of feedlot manure decreased $\mathrm{KCl}$ extractable $\mathrm{Al}$ in an acid Mollisol from Oklahoma. The addition of $1.0 \mathrm{~g} / \mathrm{kg}$ of feedlot manure decreased $\mathrm{KCl}$ extractable $\mathrm{Al}$ by $8.6 \mathrm{mg} / \mathrm{kg}$, whereas $1.0 \mathrm{~g} / \mathrm{kg}$ of poultry litter decreased this parameter by $12.1 \mathrm{mg} / \mathrm{kg}$. The larger reduction in $\mathrm{KCl}$ extractable $\mathrm{Al}$ caused by poultry litter was attributed to precipitation of $\mathrm{Al}$ by greater levels of $\mathrm{P}$ compounds present in poultry litter as compared to feedlot manure. On the basis of equilibrium constants, Iuliano et al. (2008) suggested that the fixation of soluble phosphates in soils implicates the formation of variscite $\left(\mathrm{AlPO}_{4} \cdot 2 \mathrm{H}_{2} \mathrm{O}\right)$, a reaction that will decrease the concentration of exchangeable $\mathrm{Al}^{3+}$. 
Considering the fact that the application of $20 \mathrm{t} / \mathrm{ha}$ of broiler litter neutralized $0.89 \mathrm{cmol}_{\mathrm{c}} / \mathrm{kg}$ of $\mathrm{Al}^{3+}$ in Consumo soil, and $1.81 \mathrm{cmol}_{\mathrm{c}} / \mathrm{kg}$ in Corozal soil, we would expect the neutralization of all the exchangeable $\mathrm{Al}^{3+}$ in Coto clay. However, this is not the case. In spite of having only $0.29 \mathrm{cmol}_{c} / \mathrm{kg}$ of exchangeable $\mathrm{Al}^{3+}, 0.09 \mathrm{cmol}_{c} / \mathrm{kg}$ remained after the application of $20 \mathrm{t} / \mathrm{ha}$ of chicken manure. This finding is evidence of the variable nature of the exchangeable $\mathrm{Al}^{3+}$ fraction in soils. It has been suggested that exchangeable $\mathrm{Al}^{3+}$ adsorbed at organic matter sites is retained more strongly than the fraction adsorbed on mineral surfaces (Oates and Kamprath, 1983a, b). This adsorption also suggests that once a fraction of exchangeable $\mathrm{Al}^{3+}$ is removed by complexation or precipitation, the remaining exchangeable $\mathrm{Al}^{3+}$ is bound more tightly to soil particles, or it is less accessible to the extractant.

Broiler litter applications significantly increased extractable $\mathrm{Mn}$ content in Consumo and Coto soils (Table 2) and exchangeable $\mathrm{Mg}^{2+}$ content in all soils (Table 3). No significant increase was observed in exchangeable $\mathrm{Ca}^{2+}$ content with manure applications (Table 4). A significant increase in $\mathrm{K}^{+}$content was observed for all soils with broiler litter applications. Each increment of $5 \mathrm{t}$ of broiler litter increased exchangeable $\mathrm{K}^{+}$approximately by $0.12 \mathrm{cmol} / \mathrm{kg}$ (Table 5 ). Broiler litter contained $3.32 \% \mathrm{~K}$ and previous studies indicate that $\mathrm{K}$ content can be extracted almost entirely with $1 \mathrm{~N}$ ammonium acetate, thus suggesting that it is readily available to crops (Muñoz et al., 1989; O'Hallorans et al., 1993).

Highly weathered soils with high exchangeable $\mathrm{Al}^{3+}$ content have a higher capacity to adsorb the $\mathrm{P}$ present in the manure, reducing its availability to crops. However, in situations where intensive application of manure is performed such soils are more efficient in reducing risks of $\mathrm{P}$ contamination of nearby water resources. The CEC of the soils is another factor to consider under intensive manure applications because the risk of increasing soil salinity levels increases as the CEC of the soil diminishes. An analysis of $\mathrm{P}$ content of the soil should be per-

TABLE 2. Exchangeable $\mathrm{Mn}^{2+}(\mathrm{mg} / \mathrm{kg})$ as result of broiler litter applications.

\begin{tabular}{lccccc}
\hline & \multicolumn{5}{c}{ Broiler litter (t/ha) } \\
\cline { 2 - 6 } Soils & 0 & 5 & 10 & 15 & 20 \\
\hline Consumo & $25.75 \mathrm{~b}$ & $30.25 \mathrm{ab}$ & $32.50 \mathrm{a}$ & $32.25 \mathrm{a}$ & $32.50 \mathrm{a}$ \\
Corozal & $0.84 \mathrm{a}$ & $1.75 \mathrm{a}$ & $2.00 \mathrm{a}$ & $2.00 \mathrm{a}$ & $2.75 \mathrm{a}$ \\
Coto & $10.25 \mathrm{c}$ & $12.75 \mathrm{bc}$ & $17.25 \mathrm{ab}$ & $17.25 \mathrm{ab}$ & $22.25 \mathrm{a}$ \\
\hline
\end{tabular}

${ }^{1}$ Means followed by the same letter or sequence of letters on each row are not significantly different at the $5 \%$ confidence level by the Tukey test. 
TABLE 3. Exchangeable $\mathrm{Mg}^{2+}\left(\mathrm{cmol}_{\mathrm{c}} / \mathrm{kg}\right)$ as result of broiler litter applications.

\begin{tabular}{lccccc}
\hline & \multicolumn{5}{c}{ Broiler litter (t/ha) } \\
\cline { 2 - 6 } Soils & 0 & 5 & 10 & 15 & 20 \\
\hline Consumo & $5.16 \mathrm{~b}$ & $5.34 \mathrm{ab}$ & $5.41 \mathrm{ab}$ & $5.47 \mathrm{a}$ & $5.49 \mathrm{a}$ \\
Corozal & $0.50 \mathrm{c}$ & $0.61 \mathrm{bc}$ & $0.73 \mathrm{abc}$ & $0.83 \mathrm{ab}$ & $0.90 \mathrm{a}$ \\
Coto & $0.70 \mathrm{~b}$ & $0.80 \mathrm{ab}$ & $0.93 \mathrm{ab}$ & $0.93 \mathrm{ab}$ & $1.05 \mathrm{a}$ \\
\hline
\end{tabular}

${ }^{1}$ Means followed by the same letter or sequence of letters on each row are not significantly different at the $5 \%$ confidence level by the Tukey test.

TABLE 4. Exchangeable $\mathrm{Ca}^{2+}\left(\mathrm{cmol}_{\mathrm{c}} / \mathrm{kg}\right)$ as result of broiler litter applications.

\begin{tabular}{lccccc}
\hline & \multicolumn{5}{c}{ Broiler litter (t/ha) } \\
\cline { 2 - 6 } Soils & 0 & 5 & 10 & 15 & 20 \\
\hline Consumo & $6.94 \mathrm{a}$ & $7.56 \mathrm{a}$ & $7.52 \mathrm{a}$ & $7.39 \mathrm{a}$ & $7.76 \mathrm{a}$ \\
Corozal & $3.89 \mathrm{a}$ & $4.12 \mathrm{a}$ & $4.46 \mathrm{a}$ & $4.91 \mathrm{a}$ & $4.80 \mathrm{a}$ \\
Coto & $3.70 \mathrm{a}$ & $3.85 \mathrm{a}$ & $4.11 \mathrm{a}$ & $4.28 \mathrm{a}$ & $4.80 \mathrm{a}$ \\
\hline
\end{tabular}

${ }^{1}$ Means followed by the same letter or sequence of letters on each row are not significantly different at the $5 \%$ confidence level by the Tukey test.

TABLE 5. Exchangeable $K^{+}\left(\mathrm{cmol}_{\mathrm{c}} / \mathrm{kg}\right)$ as result of broiler litter applications.

\begin{tabular}{lccccc}
\hline & \multicolumn{5}{c}{ Broiler litter (t/ha) } \\
\cline { 2 - 6 } Soils & 0 & 5 & 10 & 15 & 20 \\
\hline Consumo & $0.57 \mathrm{c}$ & $0.67 \mathrm{bc}$ & $0.84 \mathrm{abc}$ & $0.95 \mathrm{ab}$ & $1.00 \mathrm{a}$ \\
Corozal & $0.90 \mathrm{~b}$ & $0.79 \mathrm{~b}$ & $1.17 \mathrm{ab}$ & $1.31 \mathrm{a}$ & $1.38 \mathrm{a}$ \\
Coto & $0.59 \mathrm{c}$ & $0.70 \mathrm{bc}$ & $0.83 \mathrm{abc}$ & $0.94 \mathrm{ab}$ & $1.10 \mathrm{a}$ \\
\hline
\end{tabular}

${ }^{1}$ Means followed by the same letter or sequence of letters on each row are not significantly different at the $5 \%$ confidence level by the Tukey test.

formed previous to intensive manure applications as a precautionary measure to reduce $\mathrm{P}$ contamination.

\section{LITERATURE CITED}

Beinroth, F. H., R. J. Engel, J. L. Lugo, C. L. Santiago, S. Ríos and G. R. Brannon, 2003. Updated taxonomic classification of the soils of Puerto Rico, 2002. Bull 303. Agric. Expt. Sta. Univ. P.R. 73 pp.

Bigham, J. M., D. C. Golden, S. W. Buol, S. B. Dixon and L. H. Bowen, 1978. Iron oxide mineralogy of well-drained Ultisols and Oxisols. II. Influence on color, surface area, and phosphate retention. Soil Sci. Soc. Am. J. 42: 825-830.

Fox, R. L., 1982. Some highly weathered soils of Puerto Rico, 3. Chemical properties. Geoderma 27: 139-176.

Guzman, G., E. Alcantara, V. Barron and J. Torrent, 1994. Phytoavailability of phosphate adsorbed on ferrihydrite, hematite, and goethite. Plant and Soil 159: 219-225. 
Jang, Y., H. Zhang, J. L. Schroder, M. E. Payton and D. Zhou, 2007. Animal manure reduces aluminum toxicity in an acid soil. Soil Sci. Soc. Am. J. 71: 1699-1707.

Jones, R. C., W. H. Hundall and W. S. Sakai, 1982. Some highly weathered soils of Puerto Rico, 2. Mineralogy. Geoderma 27: 75-137.

Haynes, R. J. and M. S. Molkolobate, 2001. Amelioration of Al toxicity and P deficiency in acid soils by additions of organic residues: A critical review of the phenomenon and the mechanisms involved. Nutr. Cycl. Agroecosyst. 59: 47-63.

Hue, N. V., 1992. Correcting soil acidity of a highly weathered Ultisol with chicken manure and sewage sludge. Comm. Soil Sci. and Plant Anal. 23: 241-264

Iuliano, M., L. Ciaviatta and G. De Tommso, 2008. The solubility constant of variscite. Soil Sci. Soc. Am. J. 72: 343-346.

Martínez, G. A., L. Olivieri, J. A. Castro, O. Muñiz-Torres and J. L. Guzmán, 1999. Phosphorus status of soils from the poultry zone in Puerto Rico. J. Agric. Univ. P. R. 83(1-2): 1-17.

Mokolobate, M. S. and R. J. Haynes, 2002. Increases in pH and soluble salts influence the effect that additions of organic residues have on concentration of exchangeable and soil solution aluminum. Eur. J. Soil Sci. 53: 481-483.

Mokolobate, M. S. and R. J. Haynes, 2003. A glasshouse evaluation of the comparative effects of organic amendments, lime and phosphate on alleviation of Al toxicity and P deficiency in an Oxisol. J. Agric. Sci. 140: 409-417.

Mount, H. R. and W. C. Lynn, 2004. Soil survey laboratory data and soil descriptions for Puerto Rico and the U.S. Virgin Islands. United States Department of Agriculture, Natural Resources Conservation Service, National Soil Survey Center, Soil Survey Investigations Report No. 49.

Muñoz, M. A., O. Colberg and J. A. Dumas, 1989. Potential of chicken manure as organic fertilizer. J. Agric. Univ. P.R. 74(2): 139-144.

Oates, K. M. and E. M. Kamprath, 1983a. Soil acidity and liming: I. Effect of the extracting solution cation and $\mathrm{pH}$ on the removal of aluminum from acid soils. Soil Sci. Soc. Am. J. 47:686-689.

Oates, K. M. and E. M. Kamprath, 1983b. Soil acidity and liming: II. Evaluation of using aluminum extracted by various chloride salts for determining lime requirements. Soil Sci. Soc. Am. J. 47: 690-692.

O'Hallorans, J. M., M. A. Muñoz and O. Colberg, 1993. Effect of chicken manure on chemical properties of a Mollisol and tomato production. J. Agric. Univ. P.R. 78(34): 181-191.

O’Hallorans, J. M., M. A. Muñoz and P. E. Márquez, 1997. Chicken manure as an amendment to correct soil acidity and fertility. J. Agric. Univ. P.R. 81(1-2): 1-8.

Tang, Y., H. Zhang, J. L. Schroder, M. E. Payton and D. Zhou, 2007. Animal manure reduces aluminum toxicity in an acid soil. Soil Sci. Soc. Amer. J. 71: 1699-1707.

Whalen, J. K., C. Chang, G. W. Clayton and J. P. Carefoot, 2000. Cattle manure amendments can increase the $\mathrm{pH}$ of acid soils. Soil Sci. Soc. Am. J. 64: 962-966.

Wong, M. T., S. Nortcliff and R. S. Swift, 1998. Method for determining the acid ameliorating capacity of plant residue compost, urban waste compost, farmyard manure, and peat applied to tropical soils. Commun. Soil Sci. Plant Anal. 29: 2927-2937. 